\title{
DAMPAK PERILAKU EKONOMI MASYARAKAT TERHADAP GANTI RUGI PENGADAAN TANAH TOL CIPALI UNTUK KEPENTINGAN UMUM
}

\author{
Sugianto dan Leiliya \\ Fakultas Syari'ah dan Ekonomi Islam \\ Institut Agama Islam Negeri Syekh Nurjati Cirebon \\ email: sugiantolkbh@yahoo.co.id dan leliya12@yahoo.co.id
}

\begin{abstract}
The public interest included the nation and the state interest and then the common interest, rights of land can be repealed with give proper compensation which is agree with law. One of them land acquisition for public interest such as Cipali Road Project as policy instruments was decided Sales Value of Taxable Object as basic calculation compesation land acquisition. The result of research is in the construction of Cipali Tollroad (CirebonPalimanan) Cirebon Regency because the construction of Cipali Tollroad is the public interest as "two sides of a coin" certainly there are two problems or impact result from Cipali Tollroad that are: 1) Positive Impact: their excursions in the region of the exit of Cipali Tollroad (Cirebon, Kuningan, Majalengka) can be increase; attract investment industry sector in districts which be passed tollroad; distribution of goods is faster, so the price of goods is cheaper and inflation also is lower; the price of soil is increased significantly, can be absorb labor in the business sector;. 2) Negative Impact: makes people who sell/attempted in along the pantura stripe is suffer a financial loss and bankruptcy; the emergency of bad debts for bank customer in along the pantura stripe "in the outside of Cipali Tollroad"; society who be running a business in along the pantura stripe as is Cipali Tollroad moved into crowded placelarea in the stripe of Tol Cipali (Cirebon-Palimanan).
\end{abstract}

Keywords: Economic Behavior, Compensation, and Public Interest.

\begin{abstract}
Abstrak
Kepentingan umum, termasuk kepentingan bangsa dan negara serta kepentingan bersama, hak-hak atas tanah dapat dicabut dengan memberi ganti kerugian yang layak dan sesuai dengan tata cara yang diatur dalam undang-undang. Salah satunya pengadaan tanah untuk Kepentingan Umum yaitu Proyek jalan tol Cipali, sebagai instrumen kebijakan telah menetapkan NJOP (Nilai Jual Obyek Pajak) sebagai dasar perhitungan kompensasi pengadaan tanah. Hasil Penelitian ini adalah dalam Pembangunan jalan Tol Cipali (Cirebon-Palimanan) Kabupaten Cirebon karena Pembangunan Jalan Tol Cipali merupakan Kepentingan Umum seperti "dua sisi mata uang " tentunya ada dua problem atau dampak akibat tol Cipali yaitu; 1) Dampak Positif: Adanya kunjungan wisata diwilayah pintu keluar tol Cipali (Cirebon, Kuningan, Majalengka) dapat meningkat; Menarik investasi sektor industri dikabupaten - kabupaten yang terlalui jalan tol; Distribusi barang lebih lancar ,sehingga harga barang lebih murah dan inflasipun rendah; Harga tanah meningkat tajam, dapat menyerap tenaga kerja pada sektor sektor dunia usaha; 2) Dampak Negatif: Menjadikan masyarakat yang berjualan/usaha disepanjang jalan pantura rugi dan gulung tikar atau bangkrut; Munculnya kredit macet bagi nasabah Bank disepanjang jalur pantura "diluar Tol Cipali"; Masyarakat yang berusaha disepanjang jalur pantura dengan adanya Tol Cipali "Pindah ke tempat/kawasan yang ramai di jalur Tol Cipali (Cirebon-Palimanan).
\end{abstract}

Kata Kunci: Perilaku Ekonomi, Ganti Rugi, dan Kepentingan Umum. 


\section{PENDAHULUAN}

Betapa pentingnya fungsi bumi, air, dan kekayaan alam yang terkandung di dalamnya dalam pembangunan nasional untuk mewujudkan masyarakat yang adil dan makmur.Untuk mewujudkan hal tersebut perlu dilakukan kegiatan-kegiatan pembangunan, yang mana bagi penyelenggaraanpembangunan fisik selalu diperlukan tanah. ${ }^{1}$

Persoalan yang mengemuka saat ini adalah negara, dalam hal ini pemerintah, untuk menjalankan proyek infrastruktur dengan cepat, mudah, murah, dan tidak menimbulkan konflik atau sengketa pertanahan. Salah satu kendala lambatnya pemenuhan target-target pembangunan infrastruktur adalah ketersediaan lahan. Jika lahan itu menjadi milik warga atau kelembagaan, cara yang bisa ditempuh adalah dengan penguasaan lahan melalui pembelian oleh pemerintah. ${ }^{2}$

Dalam banyak kasus, sudah sering muncul masyarakat yang terkena dampak dari pengadaan tanah menjadi korban, standar hidup mereka tidak membaik, justru sebaliknya, yaitu: turun, terpuruk, miskin dan kemudian hidup dalam kondisi tidak layak, tentunya hal itu tidak kehendaki karena dalam pembangunan nasional, sejatinya semua kekayaan sumber daya alam dan seluruh tumpah darah Indonesia harus dimanfaatkan untuk sebesar-besarnya kepentingan masyarakat umum, bukan untuk keuntungan segelintir orang saja. ${ }^{3}$

Dalam Pasal 27 ayat (2) UUD 1945 merupakan ukuran yang penting dalam menentukan batas toleransi pengesampingan atau pencabutan hak milik perseorangan demi kepentingan umum, yaitu bahwa tidak seorang warga negara pun boleh dikurangi atau dicabut hak miliknya atas tanah,

\footnotetext{
${ }^{1}$ Boedi Harsono, Hukum Agraria (Jakarta: Djambatan. 1962) hal 164.

${ }^{2}$ Sudjarwo Marsoem at all, Gnti Untung pengadaan Tanah Memetakan Solusi StrategisPembanguan Infrastruktur Di Indonesia (Jakarta: Renebook, 2015), 20.

${ }^{3}$ Djuhaendah Hasan, Makalah Aspek Hukum Ekonomi dalam Pengadaan Tanah untuk Kepentingan Pembanguanan (Jakarta:2006), 14.
}

apabila karena pengurangan atau pencabutan hak miliknya itu ia akan kehilangan pekerjaan atau penghidupannya yang layak, atau sangat dikurangi kemampuan dan kemungkinan untuk menikmati penghidupan dan pekerjaan yang layak. $^{4}$

Kepentingan umum, termasuk kepentingan bangsa dan negara serta kepentingan bersama, hak-hak atas tanah dapat dicabut dengan memberi ganti kerugian yang layak dan sesuai dengan tata cara yang diatur dalam undang-undang. Salah satunya pengadaan tanah untuk Kepentingan Umum Yaitu Proyek jalan tol Cipali itu, sebagai instrumen kebijakan telah menetapkan NJOP (Nilai Jual Obyek Pajak) sebagai dasar perhitungan kompensasi pengadaan tanah. NJOP juga menjadi rujukan utama dalam proses negosisasi dan musyawarah penetapan nilai kompensasi dengan para pemilik tanah.

Berdasarkan urain di atas, muncul beberapa pertanyaan yang hendak dijelaskan lebih lanjut dalam penelitian kali ini, yaitu pertama, bagaimana dampak perilakuekonomi masyarakat terhadap ganti rugi pengadaan tanah Tol Cipali untuk kepentingan umum? Dan kedua, bagaimana peran Badan Pertanahan Nasional (BPN)dalam pengadaan tanah Tol Cipali untuk kepentingan umum?

\section{KERANGKA TEORI}

Dalam UUD 1945 Pasal 27 ayat (2) merupakan ukuran yang penting dalam menentukan batas toleransi pengesampingan atau pencabutan hak milik perseorangan demi kepentingan umum; yaitu bahwa tidak seorang warga negara pun boleh dikurangi atau dicabut hak miliknya atas tanah, apabila karena pengurangan atau pencabutan hak miliknya itu ia akan kehilangan pekerjaan atau penghidupannya yang layak, atau sangat dikurangi kemampuan dan kemungkinan untuk menikmati penghidupan dan pekerjaan yang

\footnotetext{
${ }^{4}$ Sunaryati Hartono, Hukum Pembangunan Ekonomi Pembangunan Indonesia (Bandung: Binacipta. 1988), 134-135.
} 
layak. Sehingga apabila ternyata bahwa tidak ada jalan lain dari pada mencabut hak milik perseorangan itu, maka warga negara yang dicabut atau dikurangi hak miliknya harus diganti hak sedemikian rupa, sehingga ia akan terjamin kembali haknya atas pekerjaan dan penghidupan yang layak. ${ }^{5}$

Perlu diketahui bahwa untuk kepentingan umum, termasuk kepentingan bangsa dan negara serta kepentingan bersama, hak-hak atas tanah dapat dicabut dengan memberi ganti kerugian yang layak dan sesuai dengan tata cara yang diatur dalam undang-undang. Salah satunya Pengadaan Tanah untuk Kepentingan Umum yaitu proyek jalan tol Cipali itu, berbagai instrumen kebijakan telah menetapkan NJOP (Nilai Jual Obyek Pajak) sebagai dasar perhitungan kompensasi pengadaan tanah. NJOP juga menjadi rujukan utama dalam proses negosisasi dan musyawarah penetapan nilai kompensasi dengan para pemilik tanah. ${ }^{6}$

\section{METODE PENELITIAN \\ Pendekatan Penelitian}

Penelitian ini menggunakan pendekatan kualitatif, menginvestigasi dan memahami fenomena seperti apa yang terjadi mengapa terjadi dan bagaimana terjadinya, sekaligus memahami suatu situasi social, peristiwa, peran interaksi. Hal ini dikarenakan pada penelitian ini peneliti menggunakan berbagai sumber data, teori, metode, dan investigator agar informasi yang disajikan konsisten.

Pengumpulan data dalam penelitian kualitatif kualitas riset sangat tergantung pada kualitas dan kelengkapan data yang dihasilkan. Pertanyan yang selalu dpperhatikan dalam pengumpulan data adalah apa, siapa, dimana, kapan, dan bagaimana. dalam penelitian ini digunakan

\footnotetext{
${ }^{5}$ Sunaryati Hartono, Hukum Pembangunan Ekonomi Pembangunan Indonesia (Bandung: Binacipta, 1988), 134-135

${ }^{6}$ Sudjarwo Marsoem at all, Gnti Untung pengadaan Tanah Memetakan Solusi Strategis Pembanguan Infrastruktur Di Indonesia (Jakarta: Renebook, 2015), 102
}

teknik pengumpulan data yaitu wawancara, observasi dan analisis dokumen.

\section{Fokus Penelitian}

Fokus penelitian yang dibahas dalam penelitian ini adalah dampak perilaku ekonomi masyarakat terhadap ganti rugi pengadaan tanah tol cipali untuk kepentingan umum. Untuk menghindari terlalu meluasnya masalah yang dibahas maka fokus masalah penelitian dibatasi hanya sampai pada: 1) Dampak perilaku ekonomi masyarakat terhadap ganti rugi pengadaan tanah tol cipali untuk kepentingan umum. Dan 2) Peran Badan Pertanahan Nasional dalam pengadan tanah tol cipali untuk kepentingan umum.

\section{Data dan Sumber Data Penelitian}

\section{Data primer}

Sumber ini diperoleh penulis dengan terjun langsung ke objek penelitian serta informasi-informasi yang didapat di lokasi penelitian. Penelitian lapangan adalah penelitian dengan cara terjun langsung ke lapangan untuk memperoleh data yang diperlukan dengan jalan wawancara, yaitu pengumpulan data dengan melaksanakan tanya jawab langsung dengan responden yaitu Kepala Sub Bagian Pemerintahan Desa/Kelurahan Kabupaten Cirebon, Kepala Badan Kesatuan Bangsa Dan Perlindungan Masyarakat Kabupaten Cirebon, Camat Ciwaringin Kabupaten Cirebon, Kepala kantor Badan Pertanahan Nasional Kota, Kepala Kantor Badan Pertanahan Nasional Kabupaten Cirebon, Kepala Dinas Bina Marga Kabupaten Cirebon dan Masyarakat Desa Ciwaringin.

\section{Data sekunder/teoritik}

Sumber ini diperoleh dari buku atau pustaka serta literatur lainnya yang berhubungan dengan pokok permasalahan dampak perilaku ekonomi masyarakat terhadap ganti rugi pengadaan tanah tol cipali untuk kepentingan umum. Penelitian kepustakaan adalah penelitian dengan cara membaca dan mempelajari data-data tertulis yang berupa kitab perundang-undangan, buku-buku, majalah-majalah, makalahmakalah, kliping, dan surat kabar-surat 
kabar yang berkaitan dengan permasalahan yang akan diteliti.

\section{Teknik Pengumpulan Data}

Dalam pengumpulan data, penulis menggunakan cara sebagai berikut, yaitu:

1. Wawancara

Wawancara merupakan suatu proses interaksi dan komunikasi semacam percakapan yang bertujuan untuk memperoleh informasi. Dalam penelitian ini wawancara dilakukan langsung dengan Kepala Sub Bagian Pemerintahan Desa / Kelurahan Kabupaten Cirebon, Kepala Badan Kesatuan Bangsa Dan Perlindungan Masyarakat Kabupaten Cirebon, Camat Ciwaringin Kabupaten Cirebon, Kepala kantor Badan Pertanahan Nasional Kota, Kepala Kantor Badan Pertanahan Nasional Kabupaten Cirebon, Kepala Dinas Bina Marga Kabupaten Cirebon dan Masyarakat Desa Ciwaringin.

2. Dokumentasi

Dokumentasi yaitu data-data yang diperoleh dari dokumen-dokumen yang ada di Kabupaten, Kecamatan, Desa.

3. Kepustakaan

Yaitu teknik pengumpulan data untuk mencari konsep-konsep yang ada relevansinya dengan topik pembahasan yang akan dteliti yakni internet, brosur, bukubuku, dan dokumen lainnya yang ada di kabupaten, kecamatan, desa.

\section{Teknik Penentuan Sampel}

Penentuan sampel dilakukan dengan tekniknon random sampling, yaitu tidak memberikan kesempatan yang sama kepada setiap individu untuk menjadi anggota sampel. Bentuk metode non random sampling yang akan dipakai adalah "Purposive Sampling". Dalam purposive sampling ini "peneliti menggunakan pertimbangannya sendiri dengan bekal pengetahuan yang cukup tentang populasi untuk memilih anggota-anggota sampel".

Ukuran yang digunakan dalam penentuan sampel adalah klasifikasi jumlah skore variabel lemah suatu desa berdasarkan buku petunjuk penentuan desa yang diperoleh dari Kepala Sub Bagian
Pemerintahan Desa/Kelurahan Kabupaten Cirebon yang dikategorikan desa yang masyarakatnya terkena pembebasan tanah untuk pengadaan tanah Tol Cipali. Desadesa tersebut adalah Desa Ciwaringin, Desa Babakan, Desa Budur, Desa Gala Gamba.

Adapun cara menentukan populasi dan sampel adalah sebagai berikut, pertama, populasi adalah keseluruhan objek yang akan diteliti yaitu Dampak Perilaku Ekonomi Masyarakat Terhadap Ganti Rugi Pengadaan tanah Tol Copali Untuk Kepentingan Umum. Populasi dalam penelitian ini menyangkut 1 Kecamatan dan 4 Desa. Dan kedua, sampel adalah bagian dari kumpulan obyek penelitian yang dipelajari dan diamati. Sampel juga merupakan bagian dari populasi yang akan diteliti dan yang dianggap dapat menggambarkan populasi. Menurut Arikunto, "untuk sekedar ancer-ancer maka apabila populasinya kurang dari 100 , lebih baik diambil semua sehingga penelitiannya merupakan penelitian populasi, selanjutnya jika jumlah subjeknya lebih besar dapat diambil antara $10-15 \%$ atau $20-25 \%$ atau lebih". Adapun sampel dalam penelitian ini menggunakan random sampling, yaitu $10 \%$ sehingga sampel yang diteliti sebanyak1 Kecamatan dan 4 Desa.

Responden yang diharapkan dapat memberikan data yang dibutuhkan adalah sebagai berikut; 1) Kepala Dinas Bina MargaKabupaten Cirebon. 2) Kepala Badan Kesatuan Bangsa dan perlindungan masyarakat Kabupaten Cirebon. 3) Kepala Kantor Badan Pertanahan Nasional Kabupaten Cirebon. 4) Kepala Kantor Badan Pertanahan Nasional Kota Cirebon. 5) Camat Ciwaringin di Kabupaten Cirebon. 6) Masyarakat yang terkena pengadaan tanah Tol Cipali meliputi; Masyarakat Desa Ciwaringin, Masyarakat Desa Babakan, Masyarakat Desa Budur, dan Masyarakat Desa Gala .

\section{Teknik Analisis Data}

Teknik analisa data yang digunakan dalam penelitian ini adalah teknik analisa kualitatif dengan mengumpulkan data-data yang diperoleh kemudian dideskripsikan sehingga 
dapat memberikan gambaran umum tentang Danpak Perilaku Ekonomi Masyarakat Terhadap Pengadaan Tanah Tol Cipali Untuk Kepentingan Umum.

\section{DAMPAK PERILAKU EKONOMI MASYARAKAT TERHADAP GANTI RUGI PENGADAAN TANAH TOL CIPALI UNTUK KEPENTINGAN UMUM}

Kecamatan ciwaringin sebagai salah satu wilayah hukum Pemerintah Daerah Kabupaten Cirebon yang membawahi delapan (8) desa yaitu Desa Ciwaringin, Desa Babakan, Desa Budur, Desa Galagamba, Desa Gintung Ranjeng, Desa Gintung Kidul, Desa Gintung Tengah, Desa Bringin. Kecamatan Ciwaringin adalah salah satu tempat yang terkena pembebasan tanah untuk pengadaan tol cipali dan dari kedelapan desa tersebut yang tanah hak milik masyarakat dan hak milik desa dilepas untuk pengadaan tol cipali adalah meliputi empat (4) desa yaitu Desa Ciwaringin, Desa Budur, Desa Galagamba, Desa babakan.

Berdasar hasil wawancara dengan Sahrini warga Desa Ciwaringin yang tanah hak miliknya berposisi strategis dekat jalan raya sehingga mempunyai nilai ekonomis yang tinggi, tanah tersebut dilepas untuk pengadaan tol cipali untuk kepentingan umum bahwa pembebasan tanah yang telah dilakukan pemerintah terhadap tanah hak miliknya menikmati ganti untung atau berdampak positif dikarenakan hasil dari ganti untung yang diperolehnya dapat digunakan kembali untuk modal usaha dan untuk membeli sebuah rumah layak huni.

Hal yang berbeda dialami oleh Kusnadi Warga Desa Galagamba Kecamatan Ciwaringin tanah sawah hak miliknya yang terkena pembebasan tanah untuk pembanguan tol cipaliuntuk kepentingan umum mengalami kerugian (Ganti Rugi) atau berdampak negatif dikarenakan tanah sawah yang dilepas hanya sebagain dengan posisi yang merugikannya, karena sebagian sisa tanah yang telah dilepas mempunyai peta tanah sawah yang mengerucut sehingga menjadi tidak produktif dan juga tidak memiliki nilai dijual dikarenakan tidak memiliki nilai ekonomis.

Menurut Aditya Arif Maulana selaku Kasubag Pemerintahan Desa Kabupaten Cirebon bahwa selain Tanah Milik Masyarakat tersebut terdapat pula tanah desa yang dilepas untuk pengadaan tanah dalam rangka pembangunan jalan Tol Cipali yaitu dalam bentuk tanah sawah, tanah pangonan, tanah lapang. Dalam penggantian atau proses ganti rugi oleh pemerintah untuk tanah desa yang dilihat 3 aspek penilaian, yaitu pertama, luas lahan; kedua, nilai produktif pertanian; dan ketiga, nilai ekonomi.

Dalam pengadaan tanah untuk Kepentingan Umum dalam hal ini Pembangunan Jalan Tol Cipali (Cikampek Palimanan) dalam Undang-Undang No 2 Tahun 2012 yang di tiundak lanjuti dalam Peraturan P emerintah No. 71 Tahun 2012 dalam pasal 30 ditegaskan bahwa tidak ada dampak terhadap masyarakat karena dilakukan terlebih dahulu ada musyawah antara masyarakat dengan Pemerintah dalam hal ini Panitia Pengadaan tanah untuk kepentingan umum yang di bentuk Gubernur sebagai Unsur Pemerintah Pusat yang ada di Daerah Propinsi Jawa Barat.

Dampak terhadap masyarakat adanya pembebasan tanah untuk pembangunan pengadaan jalan Tol Cipali, karena masyarakat yang terkena sasaran pembangunan pengadaan jalan Tol Cipali di berikan hak Konsultasi Publik selama 30 (tiga puluh) hari dalam hal pemberian ganti rugi yang layak sesuai yang di sepakati kedua belah pihak yang dilakukan antara masyarakat dengan Pemerintah tentang besaran Ganti rugi tanah pengganti atau dalam bentuk Uang, dengan hal tersebut masyarakat tidak di rugikan selama dilakukan ada kesepakatan sesuai yang ditegaskan dalam Undang-Undang Nomor 2 Tahun 2012 dalam pasal 33 dengan ketentuan sebagai berikut :- Penilaian besarnya ganti kerugian dilakukan oleh team penilai dalam bentuk tanah Pengganti, Ruang atas tanah dan bawah tanah, Bangunan, tanaman, benda yang berkaitan 
dengan tanah dan kerugian lain yang dapat di nilai.

Dalam Pembangunan jalan Tol Cipali (Cirebon-Palimanan) Kabupaten Cirebon karena Pembangunan Tol Cipali merupakan Kepentingan Umum seperti "dua sisi mata uang" tentunya ada dua Problem atau dampak akibat tol Cipali yaitu pertama, dampak Positif, meliputi; 1) adanya kunjungan wisata diwilayah pintu keluar tol Cipali (Cirebon-Cirebon, Kuningan, Majalengka) dapat meningkat, 2) menarik investasi sektor industri dikabupaten kabupaten yang terlalui jalan tol, 3) distribusi barang lebih lancar, sehingga harga barang lebih murah dan inflasipun rendah, 4) harga tanah meningkat tajam, dapat menyerap tenaga kerja pada sektor sektor dunia usaha.

Dan kedua, dampak Negatif, meliputi; 1) menjadikan masyarakat yang berjualan/usaha disepanjang jalan pantura rugi dan gulung tikar atau bangkrut, 2) munculnya kredit macet bagi nasabah Bank disepanjang jalur pantura "diluar Tol Cipali", 3) masyarakat yang berusaha disepanjang jalur pantura dengan adanya Tol Cipali "Pindah ke tempat/kawasan yang ramai di jalur Tol Cipali (Cirebon Palimanan).

\section{Peran Badan Pertanahan Nasional (BPN) dalam Pengadaan Tanah Tanah Tol Cipali untuk Kepentingan Umum}

Peran BPN dalam Pengadaan Tanah untuk Kepentingan Umum.Dalam UndangUndang Nomor 2 tahun 2012 Pasal 1 angka 14 Badan Pertanahan Nasional (BPN) sebagai lembaga/Instansi Pemerintah yang menyelenggarakan urusan Pemerintahan dibidang Pertanahan yang ditindak lanjuti dalam Peraturan Presiden (Perpres) Nomor 20 tahun 2015 Pasal 3 huruf (n) salah satunya mempunyai tugas fungsi pengkajian dan penanganan masalah, sengketa, perkara dan konflik di bidang pertanahan. Tugas pokok dan fungsi Deputi Bidang Pengkajian dan Penanganan Sengketa dan Konflik Pertanahan dalam perumusan kebijakan teknis di bidang pengkajian dan penanganan sengketa dan konflik pertanahan disertai pengkajian dan pemetaan secara sistematis berbagai masalah, sengketa dan konflik pertanahan secara hukum dan secara Musyawarah, penanganan perkara pertanahan, pelaksanaan alternatif penyelesaian masalah, sengketa dan konflik pertanahan melalui bentuk mediasi, fasilitasi dan lainnya, pelaksanaan putusan-putusan lembaga peradilan yang berkaitan dengan pertanahan untuk penyiapan pembatalan dan penghentian hubungan hukum antara orang dan/atau badan hukum dengan tanah sesuai dengan ketentuan peraturan perundangundangan yang berlaku.

Berdasarkan Keputusan Kepala BPNRI Nomor 34 Tahun 2007 disusun Petunjuk Teknis Penanganan dan Pengaduan masalah pertanahan.Salah satu fungsi Deputi Bidang Pengkajian dan Penanganan Sengketa dan Konflik Pertanahan adalah menyelenggarakan pengkajian dan pemetaan secara sistematis berbagai masalah, sengketa dan konflik pertanahan.

Berkaitan dengan fungsi BPN dalam hal penyelesaian sengketa pertanahan, dalam pengadaan tanah untuk kepentingan umum" yaitu Pembangunan Jalan Tol Cipali (Cirebon- Palimanan) sepertinya keberadaan sistem pengelolaan pengaduan (SPP) sebagai prasyarat terwujudnya sistem penyelesaian sengketa yang efektif dengan mensyaratkan sebagai berikut; 1) Definisi tentang subyek pengadu. 2) Penegasan bahwa pengaduan merupakan hak setiap orang dan didasarkan pada asas praduga tak bersalah. 3) Tersedianya tata cara penanggapan pengaduan. 4) Mekanisme verifikasi yang bersifat transparan dan akuntabel. 5) Adanya batas waktu penyelesaian pengaduan. 6) Dijaminnya akses publik terhadap informasi tentang proses dan hasil kerja pengelola pengaduan. 7) Kewajiban instansi penerima pengaduan untuk memfasilitasi penyelesaian sengketa melalui Alternative Dispute Resolution (ADR) apabila hasilnya layak untuk ditindaklanjuti.

Berdasarkan hasil wawancara dengan Judiansyah Selaku Kepala Sub Seksi Pengadaan tanah pemerintah Badan Pertanahan Nasional Kabupaten Cirebon 
dan diperkuat Peraturan Presiden Nomor 71 Tahun 2012 Pengadaan Tanah serta Undang-Undang Nomor 2 Tahun 2012 tentang Pengadaan Tanah bagi Pembangunan untuk Kepentingan Umum. Dalam hal ini untuk pengadaan tol cipali menyangkut kepentingan umum mencakup empat tahap, yaitu pertama, perencanaan, pada tahap perencanaan meliputi sosialisasi kepada masyarakat tentang perencanaan pembangunan untuk kepentingan umum dan pendataan awal objek yang terkena pengadaan tanah, status tanah, luas tanah dan diakhiri dengan pembuatan berita acara kesepakatan dengan masyarakat untuk penetapan lokasi.

Kedua, persiapan, pada tahap persiapan meliputi kegiatan sebagai berikut; 1) musyawarah Ganti Rugi, 2) pengukuran, 3) pendataan masing-masing tanah, 4) bangunan, 5) tanaman, 6) bangunan yang bernilai, 7) persetujuan Ganti Rugi

Ketiga, pelaksanaan, pada tahap pelaksanaan terdapat kegiatan pembayaran ganti rugi yang diikuti dengan pelepasan Hak Atas Tanah (HAT) kepemilikkan tanah oleh Badan Pertanahan Nasional (BPN).

Dan keempat, penyerahan Hasil, pada tahap penyerahan hasil terdapat berita acara hasil persiapan pembebasan tanah untuk kepentingan umum yang kemudian diserahkan ke pihak yang terkait dan berkepentingan yaitu Jasa Marga.

Pada tahap pengadaan tanah tersebut BPN Kabupaten Cirebon berperan dengan beberapa pihak terkait yaitu: 1) Pemerintah Daerah Kebupaten Cirebon (Pemda), 2) Dinas Pekerjaan Umum (PU), 3) Badan Perencanaan Pembangunan Daerah (Bappeda), 4) Dinas Cipta Karya, 5) Camat, 6) Lurah/ Kepala Desa/ Kuwu

\section{KESIMPULAN}

Berdasarkan uraian di atas, dapat diambil 2 (dua) kesimpulan, yaitu pertama, dalam proses pengadaan tanah bagi pembangunan untuk kepentingan umum melalui pembebasan tanah dilaksanakan tidak hanya dengan cara musyawarah dan pelepasan hak tapi dapat ditempuh dengan menerapkan solusi aspek hukum, solusi aspek penilaian aset. Apabila dengan berbagai cara telah ditempuh dan tidak terjadi kesepakatan sedangkan pembangunan sangat dibutuhkan, pencabutan hak atas tanah menjadi pilihan terakhir yang diatur dalam UU No. 2 tahun 2012 yang ditindak lanjuti dalam PP 71 tahun 2012 tentang pengadaan tanah bagi pembangunan untuk kepentingan umum. Proses penyelesaian sengketa pertanahan selain melalui Pengadilan Umum juga dapat ditempuh melalui Alternatif Penyelesaian Sengketa (APS) melalui proses Negosisasi, Mediasi, Konsiliasi dan Arbitrase. Selain itu adanya Lembaga atau Institusi penyelesaian sengketa seperti Badan Pertanahan Nasional, Lembaga Peradilan dalam penyelesaian sengketa melalui upaya Land Reform.Pengadaan tanah untuk kepentingan kepentingan umum dalam hal ini pembangunan Jalan Tol Cipali (Cirebon Palimanan) dilakukan dengan cara pembebasan tanah oleh pemerintah dengan memberikan ganti rugi kepada warga masyarakat yang berhak. Nilai kompensasi dari Nilai Jual Obyek Pajak, dibedakan antara status kepemilikan hak atas tanah yang bersertifikat dengan yang tidak bersertifikat.

Dan kedua, peran Badan Pertanahan Nasional dalam pengadaan tanah untuk kepentingan umum dalam Undang-Undang Nomor 2 tahun 2012 pasal 1 angka 14 Badan Pertanahan Nasional sebagai lembaga atau instansi pemerintah yang yang menyelenggarakan urusan pemerintah di bidang pertanahan yang ditindaklanjuti dalam Peraturan Presiden Nomor 20 Tahun 2015 pasal 3 huruf (n) salah satunya memiliki tugas dan fungsi pengkajian dan penanganan masalah sengketa di bidang pertanahan, disamping itu Badan Pertanahan Nasional juga berperan dalam pelaksanaan tahapan pengadaan tanah untuk pembangunan tol cipali dalam tahap perencanaan, tahap persiapan, tahap pelaksanaan dan tahap penyerahan hasil. 


\section{DAFTAR PUSTAKA}

Aprillia, et.all. Pembangunan Berbasis Masyarakat. Bandung: Alfabet, 2014.

Harsono, Budi. Hukum Agraria. Jakarta: Djambatan, 1962.

Hasan, Djuhaendah. Makalah: Aspek Hukum Ekonomi dalam Pengadaan Tanah untuk Kepentingan Pembanguanan. Jakarta: ttp., 2006.

Mardikanto, Totok, et.all. Pemberdayaan Masyarakat. Bandung: Alfabeta, 2013.

Mohammad Hatta, Hukum Tanah Nasional, Media Abadi, Yogyakarta, 2014.

Bab-bab tentang
Perolehan dan Hapusnya Hak Atas Tanah. Yogyakarta: Liberty, 2014.

Mudakir Iskandarsyah. Pembebasan Tanah untuk Pembanguan Kepentingan Umum. Jakarta: Permata Aksara, 2015.

Nasution, S. dan Thomas M. Buku Penuntun Membuat Thesis, Skripsi, Disertasi, Makalah. Jakarta: Bumi Aksara, 1994.

Peter, Hagul. Pembangunan Desa dan Lembaga Swadaya Masyarakat. Jakarta: CV. Rajawali, 1985.

Sastramiharja Zaenal Arifin. Pendekatan Pembangunan Pedesaan, Kantor Pembangunan Masyarakat Desa Pemerintah Provinsi Jawa Barat, 1995.

Simarmata, Dj. A. Ekonomi Pertanahan di Indonesia, Rajawali press, Jakarta: Rajawali Press, 2007.

Sujarwo Marsoem, at all. Gnti Untung pengadaan Tanah Memetakan Solusi Strategis Pembanguan Infrastruktur di Indonesia. Jakarta: Renebook, 2015.

Sumardjono, Maria. S. W. Pedoman Pembuatan Usulan Penelitian, Yogyakarta: ttp., 1989.

Sunaryati Hartono. Hukum Pembangunan Ekonomi Pembangunan Indonesia. Bandung: Binacipta, 1988.

Syarief, Elza. Menuntaskan Sengketa Tanah. Jakarta: PT. Gramedia, 2012.

Usman Sunyoto. Pembangunan dan Pemberdayaan Masyarakat. Yogyakarta: Pustaka Pelajar, 2010.
Wiradi, Gunawan. Reforma Agraria Perjalanan Belum Berakhir. Yogyakarta: Pustaka Pelajar, 2000.

Waty Suwarty Hartono. Hukum Lingkungan. Jakarta: UIJ, 2011. 